\title{
Copper influence on bank vole's (Myodes glareolus) sexual behavior
}

\author{
Agata Miska-Schramm ${ }^{1} \cdot$ Joanna Kapusta ${ }^{1} \cdot$ Małgorzata Kruczek $^{1}$
}

Accepted: 14 January 2018 / Published online: 2 February 2018

(c) The Author(s) 2018. This article is published with open access

\begin{abstract}
The impact of human activity on the environment has led to a steady increase of the amounts of copper in the ecosystems. This element accumulates in plants and water, potentially exposing rodents to its harmful effects. In industrial districts, a decrease in the density of small rodent populations has been observed. This decline may be caused by many factors, including mortality, decreased fertility, or impaired sexual behavior. The decline in the reproductive abilities of small rodents after copper exposure was demonstrated in our previous work (Miska-Schramm A, Kruczek M, Kapusta J, Ecotoxicology 23:1546-1554, 2014). The aim of the presented research was to determine how copper administered at concentrations similar to those recorded in industrial districts (Cu I-150 mg/kg, Cu II-600 mg/kg, C-control) affects the sexual behavior of small rodents. The model species was the bank vole (Myodes glareolus). The behavior and vocalizations of male-female

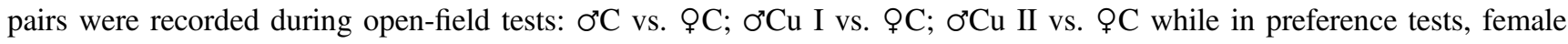

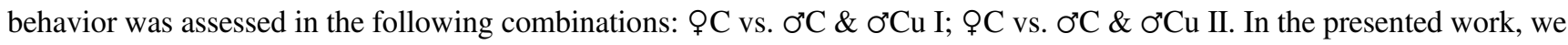
show that copper decreased the males' sexual attractiveness. Females showed suppressed preference towards males treated with $600 \mathrm{mg} / \mathrm{kg}$ copper. The number of sniffs and a number of approaches towards $\mathrm{Cu}$ II males was significantly lower than towards control individuals. Also, in preference test with $150 \mathrm{mg} / \mathrm{kg}$ treated animals, total activity was lower towards copper treated animals. At the same time, copper did not influence intra-sexual interactions.
\end{abstract}

Keywords Copper $\cdot$ Bank vole $\cdot$ Sexual behavior $\cdot$ Preference test

\section{Introduction}

One of the most serious problems of the rapid industrial development is contamination by physiological substances occurring at excessive levels. Plants growing on contaminated soil may accumulate substantial concentrations of different metals, and then these plants may be ingested by herbivores (Wijnhoven et al. 2007). For animals living in polluted areas, often the only sources of water are contaminated. Significant concentrations of different metals have been found in the tissues of such animals (GdulaArgasinska et al. 2004; Martiniakova et al. 2012; Martiniakova et al. 2011; Nikolov et al. 2010; Ullah et al. 2014; Wijnhoven et al. 2007; Zounkova et al. 2014). At the same time, in industrial districts a decline in the density of rodent

Agata Miska-Schramm

agata.miska.schramm@gmail.com

1 Institute of Environmental Sciences, Jagiellonian University, Gronostajowa 7, 30-387 Krakow, Poland populations has been widely observed (Kataev et al. 1994; Sheffield et al. 2001). There is no overall data available explaining this phenomenon. One of the reasons may be the altered reproduction of small rodents. Our previous studies have shown that excess of copper, a physiological trace element which, in extreme concentrations, may lead to degenerative changes in an organism (Brewer 2007; Brewer 2010), negatively influence reproductive abilities of small rodent males mainly by declining their sperm quality and quantity (Miska-Schramm et al. 2014). Therefore, it may potentially impact their sexual behavior. This, in combination with reproductive morphological parameters, influences reproductive success of the population. The model species in our experiment is the bank vole (Myodes glareolus, Schreber 1780). This animal was selected for several reasons.

The bank vole is thought to be the most common rodent species in Europe and Asia. It is a polyphagous species showing high plasticity in dietary requirements and undergoing large changes in diet during the annual cycle (Macdonald 2001). Generally the bank vole feeds mostly on herbs and tree seeds; it also supplements its diet with 
invertebrates (Eccard and Ylönen 2001; Eccard and Ylönen 2006). Plants growing on polluted sites, and the invertebrates living there, may accumulate increased amounts of copper (Chakroun et al. 2010; Lukáň 2009; Owojori and Siciliano 2012; Sękara et al. 2005). Organisms inhabiting industrial districts are exposed thorough their diet not only to metal-contaminated plants and invertebrates but also to contaminated water (Youngers et al. 2002).

For many years the bank vole was considered a polygynous species (Gipps 1985), but molecular techniques have revealed that females commonly mate with multiple males (Borkowska and Ratkiewicz 2010; Ratkiewicz and Borkowska 2000) and therefore should be considered promiscuous. Bank vole communication is based mainly on olfactory and auditory signals. The olfactory signals are highly volatile substances which can be used for longdistance communication. In the communication between conspecifics, the olfactory system plays roles in social interaction as well, as in the reproductive activity of bank voles (Marchlewska-Koj 2000). Pheromones are excreted mainly in urine and faeces, and are secreted through skin glands (Bind et al. 2013; Cheung 2008; Kannan and Archunan 2001). In sexual behavior they play an important role in enabling females to distinguish a potential mating partner, and in identifying social status or kinship (Kruczek 2007; Kruczek and Pochroń 1997). For example, rat females prefer males with stronger testosterone-controlled signals, such as male chemosignals (Xiao et al. 2004). Females show an increase of behavioral activity in response to chemosignals from dominant males (Horne and Ylönen 1996; Kruczek and Pochroń 1997), which have been shown to have better reproductive morphological parameters than subordinate ones (Kruczek and Styrna 2009).

In addition to using olfactory signals, bank voles also communicate by means of calls in two ranges: audible to humans (below $8 \mathrm{kHz}$ ) and high-frequency (ca. 20-35 kHz) (Kapusta et al. 2007; Marchlewska-Koj 2000). In nonsocial situations, the bank vole uses calls only when trapped or handled (Marchlewska-Koj 2000). In social behavior, the calls are associated with aggressive behavior during intramale encounters (Kapusta and Pochroń 2011), sexual behavior in heterosexual interaction (Kapusta and Sales 2009) and infant-mother communication (Szentgyorgyi et al. 2008). In male-female encounters, bank vole males emit ultrasounds at $30-35 \mathrm{kHz}$, depending on the male's earlier sexual experience (Kapusta et al. 1994; Marchlewska-Koj 2000). In the presence of females, sexually experienced males emit more signals than inexperienced ones (Kapusta et al. 1994). As has been shown in mice, females present a clear preference for vocalizing males over devocalized ones (Asaba et al. 2014; Hammerschmidt et al. 2009). Moreover, the response of females to male calling is clearly hormone-dependent: ovariectomized house mice show no preference for vocalizing males (Pomerantz et al. 1983). Vocal displays associated with sexual encounters are often mediated by testosterone released from the testes (Bass and RemageHealey 2008; James et al. 2008; Pasch et al. 2011).

Copper of both natural and anthropogenic origin is present in natural ecosystems (Spatari et al. 2002). In reproductive biology, copper plays an important role as a component of enzymes with activity often correlated with endocrine function, for example, in the regulation of progesterone production by luteal cells via the involvement of superoxide dismutase (Sales et al. 2011), or regulation of the production of steroid hormone by copper via inhibition of the testicular enzyme 17beta-hydroxysteroid dehydrogenaze (Chattopadhyay et al. 2005). Molecular research has shown that copper can bind with estrogen receptor- $\alpha$ $($ ER $-\alpha)$ in human breast cancer cell line MCF-7 (Martin et al. 2003). This suggests that excess copper might also bind with ER- $\alpha$ in animal organisms. In human males, copper has been found to be positively associated with testosterone, and a positive relation between the levels of testosterone and LH has also been described (Meeker et al. 2010). Copper is also associated with a nonmonotonic decrease of thyroid-stimulating hormone (TSH), which can have adverse effects on development, behavior, metabolism, reproduction and other functions (Meeker et al. 2009). $\mathrm{Ng}$ and Liu (1990) suggested a direct toxic action of copper on steroid-producing cells in the adrenal gland and testes.

According to previous study, in the bank vole, copper inhibited spermatogenic activity, as indicated by a decrease of the spermatogenic index (Miska-Schramm et al. 2014). Oral administration of copper lowered bank vole sperm quality and quantity. This was expressed by higher proportions of sperm cells with abnormal heads, lower proportions of sperm cells with correct structure of the tail cytoplasmic membrane, and also with the lower proportions of viable and mobile sperm cells (Miska-Schramm et al. 2014). That experiment used two doses of copper: basal $(150 \mathrm{mg} / \mathrm{kg})$ and elevated $(600 \mathrm{mg} / \mathrm{kg})$. Both copper doses led to lower epididymal sperm number, but only the higher dose reduced the other sperm cell parameters; the lower copper dose also increased bank vole testes weight (MiskaSchramm et al. 2014). These findings suggested that the lower dose may have accelerated selected endocrine pathways (e.g., ER- $\alpha$ ), while the higher dose was toxic to the bank vole males and harmed their reproductive parameters.

The data on the effects of excess copper on rodent females' reproductive abilities is sparse, in contrast to the large amount of research on copper deficiency in this sex (Bureau et al. 2003; Keen et al. 2003). As mentioned above, it is thought that copper in females may act through neurohormonal pathways at the level of the hypothalamus (Michaluk and Kochman 2007). In the bank vole, copper 
did not affect the number of matured ovarian follicles; a dose of $600 \mathrm{mg} / \mathrm{kg}$ reduced female body weight, while 150 $\mathrm{mg} / \mathrm{kg}$ increased relative uterus weight (Miska-Schramm et al. 2014). In view of these reproduction-related morphological disorders associated with copper, it is reasonable to suggest that copper might also modify rodents' sexual behavior. To our knowledge, only two studies have been done to test this conjecture in vertebrates: in rats, ingesting copper-enriched food led to decreased aggression levels against same-sex individuals, and it suppressed male sexual behavior in the presence of rat females (Bataineh et al. 1998; Chattopadhyay et al. 1999). Therefore, in this paper, we have addressed the question: how do the environmentally available doses of copper ( 150 and $600 \mathrm{mg} / \mathrm{kg})$ influence the sexual behavior of bank voles?

\section{Methods}

\section{Animals and housing conditions}

The bank voles (Myodes glareolus, Schreber 1780) came from the laboratory colony of the Institute of Environmental Sciences, Jagiellonian University, Krakow. The original stock was obtained in 1976 from the Mammal Research Institute of the Polish Academy of Sciences (Białowieża) and is maintained as an outbred stock colony, according to the system described by Green (1966). Briefly, each generation consists of at least 22 breeding pairs; the male and female of each mating pair do not share parents or grandparents. This breeding system ensures the heterogeneity of the colony (Green 1966). The animals are housed in polyethylene cages $(40 \mathrm{~cm} \times 25 \mathrm{~cm} \times 15 \mathrm{~cm})$ under a $14 \mathrm{~h}$ photoperiod (7 a.m. -9 p.m. light, 9 p.m. -7 a.m. dark) at 21 $\pm 1{ }^{\circ} \mathrm{C}$ and $60 \%$ humidity. Wood shavings are provided as bedding material and changed once a week. Standard pelleted chow for laboratory rodents (Labofeed H, Kcynia) and liquid in the form of deionized water or solutions of copper are available ad libitum.

For the study, at 19-20 days of age the weanlings were separated from their parents and placed in clean cages. At 4 weeks of age, 3-5 individuals were placed in same-sex cages. Then both females and males were randomly divided into three experimental groups. Starting from 4 weeks of age until the end of the experiments, the animals were treated with different metal solutions or given deionized water for 12 weeks.

\section{Experimental groups}

$\mathrm{C}$-control group given deionized water.

$\mathrm{Cu} \mathrm{I}-(150 \mathrm{mg} / \mathrm{kg}$ dose): copper sulphate (II) 5 hydrate $\left(\mathrm{CuSO}_{4} * 5 \mathrm{H}_{2} \mathrm{O}\right)$ AR purity grade (AVANTOR, Poland) at concentration of $150 \mathrm{mg} \mathrm{Cu}^{2+} / 1\left(75 \mathrm{mg} \mathrm{Cu} \mathrm{Cu}^{2+} / \mathrm{kg}\right.$ body weight/day).

$\mathrm{Cu}$ II- $(600 \mathrm{mg} / \mathrm{kg}$ dose): copper sulphate (II) 5 hydrate $\left(\mathrm{CuSO}_{4} * 5 \mathrm{H}_{2} \mathrm{O}\right)$ AR purity grade (AVANTOR, Poland) at concentration of $600 \mathrm{mg} \mathrm{Cu}^{2+} / 1\left(300 \mathrm{mg} \mathrm{Cu}^{2+} / \mathrm{kg}\right.$ body weight/day).

\section{Effect of copper on bank vole behavior}

2 weeks before the behavior tests, each 14-week-old individual was placed in a separate cage. Individuals of similar body weight were chosen for each behavioral experiment. On the day of the test the animals were transferred with their home cages to a bio-acoustic chamber for $1 \mathrm{~h}$ for habituation prior to testing.

\section{Male-female interactions}

The behavior and vocalization of male-female pairs were recorded during open-field tests in the following combinations: $0^{x} \mathrm{C}$ vs. $\$ \mathrm{C}$; $0^{x} \mathrm{Cu}$ I vs. $९ \mathrm{C}$; $0^{x} \mathrm{Cu}$ II vs. $९ \mathrm{C}$. After habituation, the female and male were transferred from their home cages to a glass vivarium $(40 \times 20 \times 25 \mathrm{~cm})$ with the floor covered with clean wood shavings. The vivarium was divided by a metal partition into two halves, each occupied by one animal, and left undisturbed for 5 min prior to the test. After this period the partition was removed, and the behavior and vocalizations were recorded for $10 \mathrm{~min}$. Observations were made between 8 a.m. and noon.

Behavior was recorded with a Sony DCR-HC30E digital camera. Sounds were recorded with an ultrasound microphone suspended $10 \mathrm{~cm}$ above the tested animals. The ultrasound microphone was connected to a QMC (UK) type S30 ultrasound detector coupled to a Sony (Japan) MZRH10 minidisk recorder. The behavior and sound recordings were started and terminated simultaneously. Twelve pairs from each of the aforementioned combinations, in which the animals approached each other during the 10-min testing period were further analyzed.

The behavior of males and females during the 10-min sessions was analyzed using a VLC Media Player.

Amicable behavior was assessed as:

- latency of nonaggressive approach (in sec) after removal of the partition; first physical contact or sniffing at distance less than $1 \mathrm{~cm}$

- number of nonaggressive approaches

- time spent sniffing (in sec)

- self-grooming (in sec)

- environment investigation (in sec).

Aggressive behavior was assessed as:

- latency of attack (in sec) after removal of the partition

- number of aggressive approaches, boxing and wrestling 
- time spent fighting (in sec).

"Approach" was defined as directional locomotion toward the other animal. A "sniff" was recorded when the individual directed its nose to within ca. $0.5 \mathrm{~cm}$ of the other individual. "Total activity" was taken as the sum of approaches and sniffs toward the other animal during the test.

The recorded signals were copied from the minidisc to a computer and analyzed using SpectraPLUS ver. 2.32 (Sound Technology Inc., Campbell, USA). Latency (in sec) and the number of emitted ultrasounds in the 10-min recording were noted.

\section{Female sexual preference}

Tests were performed in a glass vivarium divided into three equal compartments with the floor covered with clean wood shavings. The vivarium was changed to a clean one before each test. As described above, the females were transferred with their home cages to a bio-acoustic chamber for habituation for $1 \mathrm{~h}$ prior to testing. Then, $5 \mathrm{~min}$ before recording, the female was transferred from the home cage to the middle section of a vivarium. Two males anaesthetized with Vetbutal $(0.1 \mathrm{ml} / 10 \mathrm{~g}$ body weight; Biowet, Puławy, Poland) were placed in each of the two side compartments and the partitions were removed. The males were anaesthetized due to concern that their variable behavior would complicate the task of interpreting the behavioral response of the females. Female behavior was recorded in the following combinations: $\$ \mathrm{C}$ vs. $\sigma^{x} \mathrm{C} \& \mathrm{O}^{x} \mathrm{Cu} \mathrm{I}$; $\bigcirc \mathrm{C}$ vs. $\mathrm{O}^{x} \mathrm{C} \&$ $\mathrm{o}^{\top} \mathrm{Cu}$ II; namely, each female was exposed to control and $\mathrm{Cu}$ experimental group males (either $\mathrm{Cu}$ I or $\mathrm{Cu}$ II) located randomly in the vivarium. The behavior of the 12 females from each of these combinations was taped with a Sony DCR-HC30E digital video camera for $10 \mathrm{~min}$, beginning as soon as the female had sniffed each male once. The number of female-to-male approaches, the number of sniffs, and the time spent sniffing each male were measured using VLC Media Player software. Approaches and sniffs were defined as described above.

The researchers who performed and analyzed the behavioral tests were blind to the experimental group during those procedures.

\section{Statistical analysis}

The following statistical tests were used to analyze the data:

- Kruskal-Wallis one-way test for nonparametric analysis: for latency of nonaggressive approach, aggressive approach and ultrasound emission; for time of sniffs, attacks, environmental activity and self-grooming;

- One way ANOVA: number of sniffs, attacks, nonaggressive and aggressive approaches, ultrasounds;
- Post-hoc Tukey test following one way ANOVA, and Mann-Whitney $U$ test following Kruskal-Wallis one way test: to test the significance of differences between means;

- Wilcoxon matched-pairs test for dependent samples in preference tests; for number of approaches, number and duration of sniffs, total activity.

All procedures employed STATISTICA v. 10. All data are presented as mean \pm SE. The level of statistical significance was deemed to be $p<0.05$.

\section{Results}

\section{Male-female interactions}

Males and female behavior in heterosexual interaction is presented in Table 1. Copper did not affect any intrasexual behavior. There were no significant differences in latency to first approach [sec] or number of aggressive approaches and nonaggressive approaches between animals from the tested combinations ( $\sigma^{2} \mathrm{C}$ vs. $\$ \mathrm{C}$; $\mathrm{O}^{2} \mathrm{Cu} \mathrm{I}$ vs. OC; ơ $\mathrm{Cu}$ II vs. $\ \mathrm{C})$. Similarly, there were no significant differences in latency to first attack [sec], number of attacks, sniffing time [sec] or number of sniffs (Table 1) between the tested pairs. As presented in Table 1, the number of ultrasonic calls did not differ with treatment, and there were no significant differences in latency to first ultrasound [sec] between animals from the tested combinations. All tested male-female pairs of bank voles emitted ultrasounds at a mean frequency of $27-33 \mathrm{kHz}$. Table $2 \mathrm{a}$ presents female behavior towards males from the treatment groups $(\mathrm{C}, \mathrm{Cu} \mathrm{I}, \mathrm{Cu}$ II). There were no significant differences in number of female approaches (aggressive; nonaggressive) to males from the different experimental groups. No significant differences in females' sniffing behavior were found between animals from the tested pairs (number of sniffs; sniffing time [sec]). Similarly, no significant differences were found in female time spent on environmental activity [sec] or self-grooming [sec] (Table 2a) between animals from the different experimental combinations. Table $2 b$ presents the results for the behavior of males given water or the copper solutions $(\mathrm{Cu} \mathrm{I,} \mathrm{Cu}$ II) towards control females. There were no significant differences in the number of male approaches to control females (aggressive; nonaggressive; Table 2b) or in male sniffing behavior (number of sniffs; sniffing time) between animals from the tested pairs. Similarly to female behavior, there were no significant differences in male environmental activity [sec] or self-grooming [sec] (Table 2b) between the animals of the experimental groups. 
Table 1 Latency to first approach, attack, ultrasonic call; number of aggressive approaches, nonaggressive approaches, sniffs, ultrasonic calls; time of sniffing and attacks presented by control females (C) and by water or copper-treated males (C, $\mathrm{Cu} \mathrm{I} \mathrm{or} \mathrm{Cu}$ II) in 10-min open-field test

\begin{tabular}{|c|c|c|c|c|c|}
\hline & @C vs. $0^{\star} \mathrm{C}$ & OC vs. O’Cu I & OC vs. ƠCu II & & $p$ \\
\hline Latency to first approach [sec] & $77.3 \pm 19.5$ & $70.1 \pm 14.8$ & $84.9 \pm 26.8$ & $\mathrm{H}_{(2,33)}=0.01$ & NS \\
\hline Aggressive approaches [no.] & $6.7 \pm 1.4$ & $5.8 \pm 1.2$ & $4.8 \pm 1.0$ & $\mathrm{~F}_{(2,33)}=0.55$ & NS \\
\hline Nonaggressive approaches [no.] & $7.3 \pm 2.4$ & $6.9 \pm 2.2$ & $6.2 \pm 1.2$ & $\mathrm{~F}_{(2,33)}=0.07$ & NS \\
\hline Latency to first attack [sec] & $147.2 \pm 46.9$ & $197.1 \pm 71.3$ & $240.9 \pm 70.9$ & $\mathrm{H}_{(2,33)}=0.18$ & NS \\
\hline Attack time [sec] & $22.0 \pm 5.8$ & $13.9 \pm 3.4$ & $10.5 \pm 3.1$ & $\mathrm{H}_{(2,33)}=2.42$ & NS \\
\hline Sniffs [no] & $19.3 \pm 6.2$ & $17.6 \pm 3.7$ & $22.8 \pm 4.6$ & $\mathrm{~F}_{(2,33)}=0.29$ & NS \\
\hline Sniffing time $[\mathrm{sec}]$ & $99.6 \pm 26.6$ & $96.3 \pm 21.5$ & $170.5 \pm 36.7$ & $\mathrm{H}_{(2,33)}=2.63$ & NS \\
\hline Latency to first ultrasound [sec] & $89.3 \pm 25.0$ & $63.1 \pm 20.4$ & $67.8 \pm 18.0$ & $\mathrm{H}_{(2,33)}=0.82$ & NS \\
\hline Ultrasonic calls [no.] & $116.3 \pm 17.5$ & $110.6 \pm 37.8$ & $120.9 \pm 18.2$ & $F_{(2,33)}=0.96$ & NS \\
\hline
\end{tabular}

Means \pm S.E

Table 2 Latency to first approach, attack, ultrasonic call; number of aggressive approaches, nonaggressive approaches, sniffs, ultrasonic calls; time of sniffing and attacks presented by (a) control female (C) in interaction with male (C, Cu I, Cu II) or by (b) male (C, $\mathrm{Cu}$ I, $\mathrm{Cu}$ II) in interaction with control female in 10-min open-field test

\begin{tabular}{|c|c|c|c|c|c|}
\hline & @C vs. $0^{\star} \mathrm{C}$ & ○C vs. ƠCu I & ○C vs. $\sigma^{x} \mathrm{Cu}$ II & & $p$ \\
\hline \multicolumn{6}{|l|}{ (a) } \\
\hline Aggressive approaches [no.] & $3.2 \pm 0.7$ & $3 \pm 0.3$ & $2.4 \pm 0.5$ & $F_{(2,33)}=0.66$ & NS \\
\hline Nonaggressive approaches [no.] & $2.9 \pm 1.4$ & $2.7 \pm 0.9$ & $2.3 \pm 2.5$ & $\mathrm{~F}_{(2,33)}=0.92$ & NS \\
\hline Sniffs [no.] & $16.6 \pm 8.4$ & $6.9 \pm 1.9$ & $8.6 \pm 7.1$ & $\mathrm{~F}_{(2,33)}=0.35$ & NS \\
\hline Sniffing time [sec] & $32.8 \pm 11.7$ & $37.1 \pm 14.8$ & $51.7 \pm 15.0$ & $\mathrm{H}_{(2,33)}=0.91$ & NS \\
\hline Environmental activity [sec] & $108.4 \pm 30.3$ & $93.9 \pm 27.6$ & $143.4 \pm 27.1$ & $\mathrm{H}_{(2,33)}=1.92$ & NS \\
\hline Self-grooming [sec] & $19.4 \pm 7.5$ & $9.7 \pm 3.5$ & $14.9 \pm 4.6$ & $\mathrm{H}_{(2,33)}=1.11$ & NS \\
\hline \multicolumn{6}{|l|}{ (b) } \\
\hline Aggressive approaches [no.] & $3.2 \pm 0.7$ & $2.8 \pm 0.6$ & $2.4 \pm 0.5$ & $\mathrm{~F}_{(2,33)}=0.7$ & NS \\
\hline Nonaggressive approaches [no.] & $4.3 \pm 1.4$ & $4.3 \pm 1.9$ & $3.8 \pm 1.0$ & $\mathrm{~F}_{(2,33)}=0.97$ & NS \\
\hline Sniffs [no.] & $10.6 \pm 3.7$ & $10.7 \pm 2.9$ & $14.3 \pm 3.4$ & $\mathrm{~F}_{(2,33)}=0.68$ & NS \\
\hline Sniffing time $[\mathrm{sec}]$ & $58.8 \pm 20.0$ & $59.3 \pm 15.2$ & $103.9 \pm 23.4$ & $\mathrm{H}_{(2,33)}=2.45$ & NS \\
\hline Environmental activity [sec] & $94.4 \pm 21.2$ & $84.1 \pm 19.3$ & $149.0 \pm 28.3$ & $\mathrm{H}_{(2,33)}=3.47$ & NS \\
\hline Self-grooming [sec] & $14.5 \pm 4.7$ & $7.5 \pm 3.2$ & $12.1 \pm 2.8$ & $\mathrm{H}_{(2,33)}=2.1$ & NS \\
\hline
\end{tabular}

Means \pm S.E

\section{Female sexual preference}

Control female behavior towards control (C) males and those treated with $150 \mathrm{mg} / \mathrm{kg}$ copper $(\mathrm{Cu} \mathrm{I})$ is summarized in Figs. 1 and 2. Control females presented significantly higher total activity (number of approaches + number of sniffs) toward control males $(\overline{\mathrm{X}}=18.33 \pm 2.25)$ than toward males treated with $150 \mathrm{mg} / \mathrm{kg}$ copper $(\overline{\mathrm{X}}=14.08 \pm 2.48 ; p$ $<0.05)$. However, there were no significant differences in the number of female approaches to control males $(\overline{\mathrm{X}}=$ $4.75 \pm 0.99)$ and those treated with $150 \mathrm{mg} / \mathrm{kg}$ copper $(\overline{\mathrm{X}}=$ $4.33 \pm 0.93)$, nor in the number of females' sniffs of control $(\overline{\mathrm{X}}=13.58 \pm 1.88)$ and $\mathrm{Cu}$ I males $(\overline{\mathrm{X}}=10.58 \pm 2.23)$ (Fig. 1). Similarly, there were no significant differences in control females' sniffing time [sec] toward control $(\overline{\mathrm{X}}=72.50 \pm$ 12.82) and $\mathrm{Cu}$ I males $(\overline{\mathrm{X}}=49.00 \pm 11.82)$.

The results given in Figs. 3 and 4 show that females preferred control males to those treated with the higher copper dose ( $\mathrm{Cu}$ II), as shown by higher total activity towards control males $(\overline{\mathrm{X}}=26.92 \pm 2.94)$ than toward $\mathrm{Cu}$ II males $(\overline{\mathrm{X}}=20.0 \pm 2.77 ; p<0.05)$, higher number of female approaches to control males $(\overline{\mathrm{X}}=8.67 \pm 1.54)$ than to $\mathrm{Cu}$ II males $(\overline{\mathrm{X}}=7.25 \pm 1.15 ; p<0.05)$, and higher number of sniffs of control males $(\overline{\mathrm{X}}=18.5 \pm 1.96)$ than $\mathrm{Cu}$ II males $(\overline{\mathrm{X}}=12.75 \pm 1.76 ; p<0.05)$. However, there were no significant differences in sniffing time [sec] presented by control females towards $\mathrm{C}$ males $(\overline{\mathrm{X}}=56.71 \pm 8.87)$ and $\mathrm{Cu}$ II males $(\overline{\mathrm{X}}=39.15 \pm 6.81)$. 


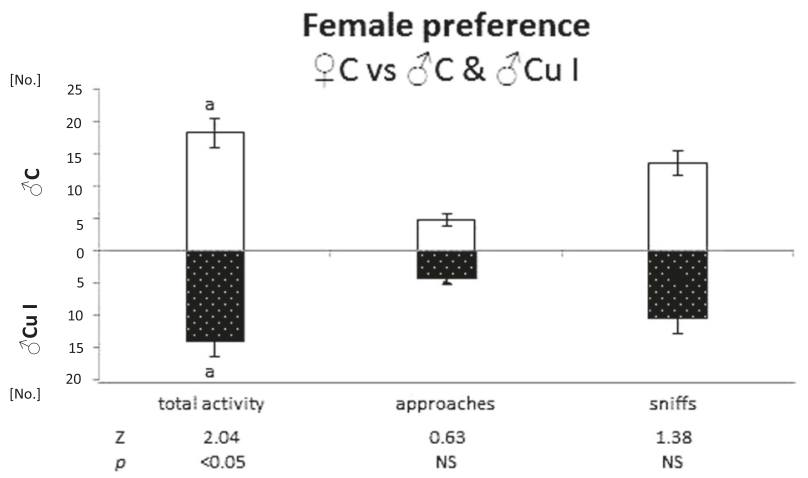

Fig. 1 Total activity, number of approaches and sniffs presented by control female towards anaesthetized male treated with $150 \mathrm{mg} / \mathrm{kg}$ copper solution $(\mathrm{Cu} \mathrm{I}$; pattern bars) and control male ( $\mathrm{C}$; open bars). Means bearing the same letter differ significantly; $a-p<0.05$. Number of tested females -12 . Means \pm S.E

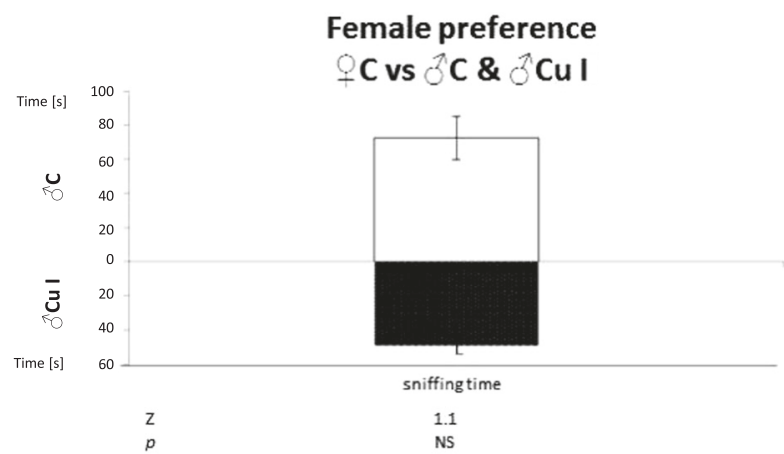

Fig. 2 Time of sniffing presented by control female towards anaesthetized male treated with $150 \mathrm{mg} / \mathrm{kg}$ copper solution $(\mathrm{Cu} \mathrm{I}$; pattern bars) and control male (C; open bars). Number of tested females-12. Means \pm S.E

\section{Discussion}

The vast majority of publications concerning the influence of copper on rodents' behavior present findings on rodent models of human diseases. So-called toxic milk mice as well as Long-Evans cinnamon rats are animal models for Wilson disease (Theophilos et al. 1996; Yoshida et al. 1987). A genetic disorder of copper metabolism occurs in those animal models as well as in human patients with Wilson disease (Ala et al. 2007; Allen et al. 2006). In those individuals, copper accumulates mainly in the liver and the brain; consequently, liver disease and neuropsychiatric symptoms are the main features that lead to a diagnosis (Ala et al. 2007). Behavioral disturbances have been observed in toxic milk mice and in Long-Evans cinnamon rats (Fujiwara et al. 2006; Przybyłkowski et al. 2013; Terwel et al. 2011).

In the context of findings on copper-induced hormonal disorders, sexual behavior might be expected to be affected by copper exposure. For this reason, our study included behavioral tests of male-female interactions. At both tested concentrations, copper did not influence bank vole social or

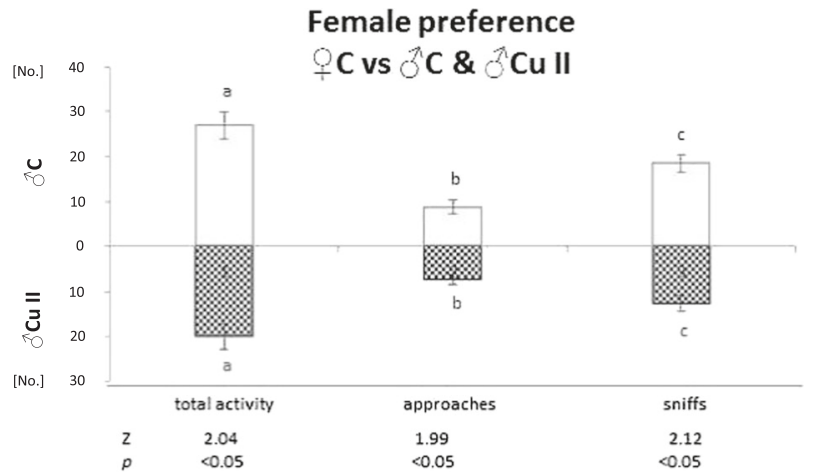

Fig. 3 Total activity, number of approaches and sniffs presented by control female towards anaesthetized male treated with $600 \mathrm{mg} / \mathrm{kg}$ copper solution ( $\mathrm{Cu}$ II; pattern bars) and control male (C; open bars); Means bearing the same letter differ significantly; a, b, $c-p<0.05$. Number of tested females-12. Means \pm S.E

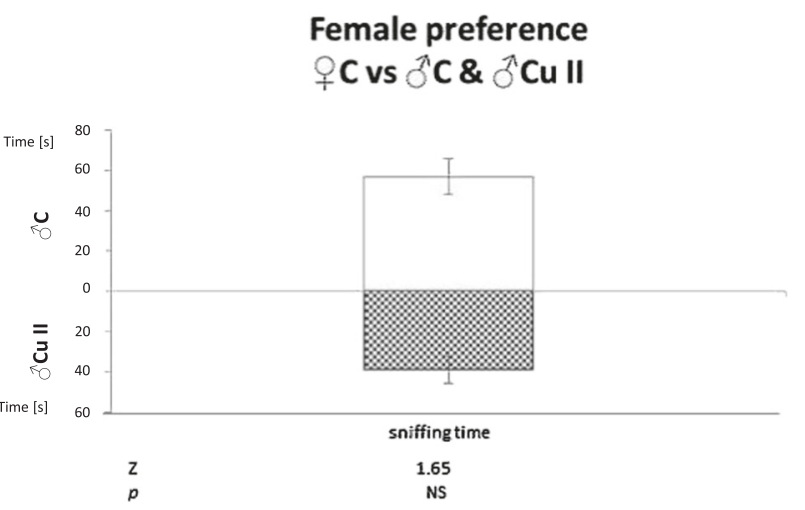

Fig. 4 Time of sniffing presented by control female towards anaesthetized male treated with $600 \mathrm{mg} / \mathrm{kg}$ copper solution $(\mathrm{Cu}$ II; pattern bar) and control male (C; open bar). Number of tested females- 12 . Means \pm S.E

aggressive behavior, in contrast to results from other research. In rats, oral administration of $200 \mathrm{mg} / \mathrm{kg}$ copper sulphate, a dose similar to the lower dose in our experiments, led to neurobehavioral abnormalities manifested in reduced latency to fall in a rotarod and lower attention percentage scores (Kumar et al. 2015). Long-term ingestion of copper chloride suppressed the sexual behavior of male rats (Bataineh et al. 1998), but that effect occurred after exposure to a much higher $\mathrm{Cu}$ dose $(1000 \mathrm{mg} / \mathrm{kg})$ than used in this study. Our experiments used copper doses equivalent to environmental levels found in polluted districts. The results of this work may better represent the effects of normally presented copper concentrations in polluted areas.

One element of sexual behavior is sexual selection. In bank voles, the females choose the sexual partner, while the males attract females using olfactory and auditory cues (Gipps 1985; Kapusta 2012; Kruczek 2007; Kruczek and Pochroń 1997). Production, excretion and emission of olfactory and auditory signals might be expected to be modified by copper. In our behavioral experiment the males 
were given copper in solution and the females were given only deionized water. We chose to use open-field twochoice preference tests to examine female sexual preference, because all research of the Mammalian Research Group has employed the same methodology, making it easy to compare results. In these tests, control females were subjected to two anesthetized males of similar size, so their choice would be based mainly on olfactory cues. The females showed a clear preference for control males when subjected to a control and a male treated with $600 \mathrm{mg} / \mathrm{kg}$ copper. Exposure to $600 \mathrm{mg} / \mathrm{kg}$ copper decreased male sexual attractiveness, probably due to disorders of olfactory cue production and excretion.

In the wild, reproductive success requires social, aggressive and sexual behavior. Based on our results, it is not possible to state that copper interferes with social and aggressive behavior, but the findings show that a high level of copper definitely interferes with olfactory cue production. Copper impairs lower vertebrates' chemical communication abilities and behavior, including sexual behavior (Lahman et al. 2015). There is no published data on rodent females' sexual preference for particular males after chronic exposure to copper. Copper may become an oxidative stress factor; in mice this stress may reduce male investment in the molecular components of olfactory signaling essential for mate attraction (Garratt et al. 2014). This mechanism might also operate in the bank vole; it would explain the females' loss of interest in males treated with $600 \mathrm{mg} / \mathrm{kg}$ copper.

Funding This study was funded by Grants from the Jagiellonian University (grant number: DS/MND/WBiNoZ/INoS'/22/2013).

\section{Compliance with ethical standards}

Conflict of interest The authors declare that they have no conflict of interest.

Ethical approval All applicable international, national, and/or institutional guidelines for the care and use of animals were followed (approval of the Regional Committee on Animal Experimentation in Krakow; Protocol No. 36/2009).

Open Access This article is distributed under the terms of the Creative Commons Attribution 4.0 International License (http://crea tivecommons.org/licenses/by/4.0/), which permits unrestricted use, distribution, and reproduction in any medium, provided you give appropriate credit to the original author(s) and the source, provide a link to the Creative Commons license, and indicate if changes were made.

\section{References}

Ala A, Walker AP, Ashkan K, Dooley JS, Schilsky ML (2007) Wilson's disease. Lancet 369:397-408. https://doi.org/10.1016/ S0140-6736(07)60196-2
Allen KJ, Buck NE, Cheah DM, Gazeas S, Bhathal P, Mercer JF (2006) Chronological changes in tissue copper, zinc and iron in the toxic milk mouse and effects of copper loading. Biometals 19:555-564. https://doi.org/10.1007/s10534-005-5918-5

Asaba A, Hattori T, Mogi K, Kikusui T (2014) Sexual attractiveness of male chemicals and vocalizations in mice. Front Neurosci 8:231. https://doi.org/10.3389/fnins.2014.00231

Bass AH, Remage-Healey L (2008) Central pattern generators for social vocalization: androgen-dependent neurophysiological mechanisms. Horm Behav 53:659-672. https://doi.org/10.1016/j. yhbeh.2007.12.010

Bataineh H, Al-Hamood MH, Elbetieha AM (1998) Assessment of aggression, sexual behavior and fertility in adult male rat following long-term ingestion of four industrial metals salts. Hum Exp Toxicol 17:570-576. https://doi.org/10.1191/ 096032798678907937

Bind RH, Minney SM, Rosenfeld S, Hallock RM (2013) The role of pheromonal responses in rodent behavior: future directions for the development of laboratory protocols. J Am Assoc Lab Anim Sci 52:124-129

Borkowska A, Ratkiewicz M (2010) Promiscuity, male reproductive success and mate relatedness in a natural population of the common vole. J Zool 280:195-201. https://doi.org/10.1111/j. 1469-7998.2009.00648.x

Brewer GJ (2007) Iron and copper toxicity in diseases of aging, particularly atherosclerosis and Alzheimer's disease. Exp Biol Med 232:323-335

Brewer GJ (2010) Copper toxicity in the general population. Clin Neurophysiol 121:459-460. https://doi.org/10.1016/j.clinph. 2009.12.015

Bureau I, Gueux E, Mazur A, Rock E, Roussel AM, Rayssiguier Y (2003) Female rats are protected against oxidative stress during copper deficiency. J Am Coll Nutr 22:239-246. https://doi.org/ 10.1080/07315724.2003.10719299

Chakroun HK, Souissi F, Bouchardon JL, Souissi R, Moutte J, Faure O, Remon E, Abdeljaoued S (2010) Transfer and accumulation of lead, zinc, cadmium and copper in plants growing in abandoned mining-district area. Afr J Environ Sci Technol 4:651-659. https://doi.org/10.5897/AJEST09.082

Chattopadhyay A, Sarkar M, Biswas NM (2005) Dose-dependent effect of copper chloride on male reproductive function in immature rats. Kathmandu Univ Med J 3:392-400

Chattopadhyay A, Sarkar M, Sengupta R, Roychowdhury G, Biswas NM (1999) Antitesticular effect of copper chloride in albino rats. J Toxicol Sci 24:393-397. https://doi.org/10.2131/jts.24.5_393

Cheung F (2008) Male pheromones that are used to attract female mice could be manipulated to attract male mice. Published online 27 August. https://doi.org/101038/nchina2008197

Eccard JA, Ylönen H (2001) Initiation of breeding after winter in bank voles: effects of food and population density. Can J Zool 79:1743-1753. https://doi.org/10.1139/z01-133

Eccard JA, Ylönen H (2006) Adaptive food choice of bank voles in a novel environment: choices enhance reproductive status in winter and spring. Ann Zool Fenn 43:2-8

Fujiwara N, Iso H, Kitanaka N, Kitanaka J, Eguchi H, Ookawara T, Ozawa K, Shimoda S, Yoshihara D, Takemura M, Suzuki K (2006) Effects of copper metabolism on neurological functions in Wistar and Wilson's disease model rats. Biochem Biophys Res Commun 349:1079-1086. https://doi.org/10.1016/j.bbrc.2006.08. 139

Garratt M, Pichaud N, Glaros EN, Kee AJ, Brooks RC (2014) Superoxide dismutase deficiency impairs olfactory sexual signaling and alters bioenergetic function in mice. Proc Natl Acad Sci USA 111:8119-8124. https://doi.org/10.1073/pnas. 1322282111 
Gdula-Argasinska J, Appleton J, Sawicka-Kapusta K, Spence B (2004) Further investigation of the heavy metal content of the teeth of the bank vole as an exposure indicator of environmental pollution in Poland. Environ Pollut 131:71-79. https://doi.org/10. 1016/j.envpol.2004.02.025

Gipps JH (1985) Spacing behaviour and male reproductive ecology in voles of the genus Clethrionomys. Ann Zool Fenn 22:343-351

Green E (1966) Breeding systems. Biology of laboratory mouse. McGraw-Hill Book Company, New York

Hammerschmidt K, Radyushkin K, Ehrenreich H, Fischer J (2009) Female mice respond to male ultrasonic 'songs' with approach behaviour. Biol Lett 5:589-592. https://doi.org/10.1098/rsbl. 2009.0317

Horne TJ, Ylönen H (1996) Female bank voles (Clethrionomys glareolus) prefer dominant males; but what if there is no choice? Behav Ecol Sociobiol 38:401-405. https://doi.org/10.1007/ s002650050257

James R, Sampath K, Jothilakshmi S, Vasudhevan I, Thangarathinam $\mathrm{R}$ (2008) Effects of copper toxicity on growth, reproduction and metal accumulation in chosen ornamental fishes. Ecohydrol Hydrobiol 8:89-97. https://doi.org/10.2478/v10104-009-0007-y

Kannan S, Archunan G (2001) Chemistry of clitoral gland secretions of the laboratory rat: assessment of behavioural response to identified compounds. J Biosci 26:247-252. https://doi.org/10. 1007/BF02703648

Kapusta J (2012) Effect of the stage of the reproductive cycle on vocalization and behaviour in female bank voles. Acta Theriol 57:145-152. https://doi.org/10.1007/s13364-011-0056-7

Kapusta J, Marchlewska-Koj A, Olejniczak P (1994) Sexual experience affects behaviour of bank voles Clethrionomys glareolus. Acta Theriol 39:365-371. https://doi.org/10.4098/AT.arch. 94-42

Kapusta J, Pochroń E (2011) Effect of gonadal hormones and sexual experience on vocalizations and behavior of male bank voles (Myodes glareolus). Can J Zool 89:1117-1127. https://doi.org/ 10.1139/z11-087

Kapusta J, Sales GD (2009) Male-female interactions and ultrasonic vocalization in three sympatric species of voles during conspecific and heterospecific encounters. Behaviour 146:939-962. https://doi.org/10.1163/156853908X396818

Kapusta J, Sales GD, Czuchnowski R (2007) Aggression and vocalization behaviour of three sympatric vole species during conspecific and heterospecific same-sex encounters. Behaviour 144:283-305. https://doi.org/10.1163/156853907780425730

Kataev GD, Suomela J, Palokangas P (1994) Densities of microtine rodents along a pollution gradient from a copper-nickel smelter. Oecologia 97:491-498. https://doi.org/10.1007/BF00325887

Keen CL, Hanna LA, Lanoue L, Uriu-Adams JY, Rucker RB, Clegg MS (2003) Developmental consequences of trace mineral deficiencies in rodents: acute and long-term effects. J Nutr 133:1477S-1480S

Kruczek M (2007) Recognition of kin in bank voles (Clethrionomys glareolus). Physiol Behav 90:483-489. https://doi.org/10.1016/j. physbeh.2006.10.012

Kruczek M, Pochroń E (1997) Chemical signals form conspecifics modify the activity of female bank vole (Clethrionomys glareouls). Acta Theriol 42:71-78

Kruczek M, Styrna J (2009) Semen quantity and quality correlate with bank vole males' social status. Behav Process 82:279-285. https://doi.org/10.1016/j.beproc.2009.07.009

Kumar V, Kalita J, Misra UK, Bora HK (2015) A study of dose response and organ susceptibility of copper toxicity in a rat model. J Trace Elem Med Biol 29:269-274. https://doi.org/10. 1016/j.jtemb.2014.06.004

Lahman SE, Trent KR, Moore PA (2015) Sublethal copper toxicity impairs chemical orientation in the crayfish, Orconectes rusticus.
Ecotoxicol Environ Saf 113:369-377. https://doi.org/10.1016/j. ecoenv.2014.12.022

Lukáň M (2009) Heavy metals in alpine terrestrial invertebrates. Oecologia 18:31-38

Macdonald D (2001) The encyclopedia of mammals. Andromeda Oxford Limited, Oxford, UK

Marchlewska-Koj A (2000) Olfactory and ultrasonic communication in bank voles. Pol J Ecol 48(Suppl):11-20

Martin MB, Reiter R, Pham T, Avellanet YR, Camara J, Lahm M, Pentecost E, Pratap K, Gilmore BA, Divekar S, Dagata RS, Bull JL, Stoica A (2003) Estrogen-like activity of metals in MCF-7 breast cancer cells. Endocrinology 144:2425-2436. https://doi. org/10.1210/en.2002-221054

Martiniakova M, Omelka R, Jancova A, Formicki G, Stawarz R, Bauerova M (2012) Accumulation of risk elements in kidney, liver, testis, uterus and bone of free-living wild rodents from a polluted area in Slovakia. J Environ Sci Health A 47:1202-1206. https://doi.org/10.1080/10934529.2012.672062

Martiniakova M, Omelka R, Jancova A, Stawarz R, Formicki G (2011) Concentrations of selected heavy metals in bones and femoral bone structure of bank (Myodes glareolus) and common (Microtus arvalis) voles from different polluted biotopes in Slovakia. Arch Environ Contam Toxicol 60:524-532. https://doi.org/ 10.1007/s00244-010-9545-y

Meeker JD, Rossano MG, Protas B, Diamond MP, Puscheck E, Daly D, Paneth N, Wirth JJ (2009) Multiple metals predict prolactin and thyrotropin (TSH) levels in men. Environ Res 109:869-873. https://doi.org/10.1016/j.envres.2009.06.004

Meeker JD, Rossano MG, Protas B, Padmanahban V, Diamond MP, Puscheck E, Daly D, Paneth N, Wirth JJ (2010) Environmental exposure to metals and male reproductive hormones: circulating testosterone is inversely associated with blood molybdenum. Fertil Steril 93:130-140. https://doi.org/10.1016/j.fertnstert.2008. 09.044

Michaluk A, Kochman K (2007) Involvement of copper in female reproduction. Reprod Biol 7:193-205

Miska-Schramm A, Kruczek M, Kapusta J (2014) Effect of copper exposure on reproductive ability in the bank vole (Myodes glareolus). Ecotoxicology 23:1546-1554. https://doi.org/10. 1007/s10646-014-1295-6

$\mathrm{Ng} \mathrm{TB}$, Liu WK (1990) Toxic effect of heavy metals on cells isolated from the rat adrenal and testis. Vitr Cell Dev Biol Anim 26:24-28. https://doi.org/10.1007/BF02624150

Nikolov IG, Joki N, Vicca S, Patey N, Auchère D, Benchitrit J, Flinois JP, Ziol M, Beaune P, Drüeke TB, Lacour B (2010) Tissue accumulation of lanthanum as compared to aluminum in rats with chronic renal failure-possible harmful effects after long-term exposure. Nephron Exp Nephrol 115:e112-e121. https://doi.org/ $10.1159 / 000313492$

Owojori OJ, Siciliano SD (2012) Accumulation and toxicity of metals (copper, zinc, cadmium, and lead) and organic compounds (geraniol and benzo[a]pyrene) in the oribatid mite Oppia nitens. Environ Toxicol Chem 31:1639-1648. https://doi.org/10.1002/ etc. 1857

Pasch B, George AS, Campbell P, Phelps SM (2011) Androgendependent male vocal performance influences female preference in Neotropical singing mice. Anim Behav 82:177-183. https:// doi.org/10.1016/j.anbehav.2011.04.018

Pomerantz SM, Nunez AA, Bean NJ (1983) Female behavior is affected by male ultrasonic vocalizations in house mice. Physiol Behav 31:91-96. https://doi.org/10.1016/0031-9384(83)90101-4

Przybyłkowski A, Gromadzka G, Wawer A, Bulska E, Jabłonka-Salach K, Grygorowicz T, Schnejder-Pachołek A, Członkowski A (2013) Neurochemical and behavioral characteristics of toxic milk mice: an animal model of Wilson's disease. Neurochem Res 38:2037-2045. https://doi.org/10.1007/s11064-013-1111-3 
Ratkiewicz M, Borkowska A (2000) Multiple paternity in the bank vole (Clethrionomys glareolus): field and experimental data. $\mathrm{Z}$ Saugetier 65:6-14

Sales JNS, Pereira RVV, Bicalho RC, Baruselli PS (2011) Effect of injectable copper, selenium, zinc and manganese on the pregnancy rate of crossbred heifers (Bos indicus x Bos taurus) synchronized for timed embryo transfer. Livest Sci 142:59-62. https://doi.org/10.1016/j.livsci.2011.06.014

Sękara A, Poniedziałek M, Ciura J, Jędrszczyk E (2005) Zinc and copper accumulation and distribution in the tissues of nine crops: implications for phytoremediation. Pol J Environ Stud 14:829-835

Sheffield SR, Sawicka-Kapusta K, Cohen JB, Rattner BA (2001) Rodentia and lagomorpha. In: Shore RF, Rattner BA (eds) Ecotoxicology of wild mammals. Wiley, New York

Spatari S, Bertram M, Fuse K, Graedel TE, Rechberger H (2002) The contemporary European copper cycle: 1 year stocks and flows. Ecol Econ 42:27-42

Szentgyorgyi H, Kapusta J, Marchlewska-Koj A (2008) Ultrasonic calls of bank vole pups isolated and exposed to cold or to nest odor. Physiol Behav 93:296-303. https://doi.org/10.1016/j. physbeh.2007.09.015

Terwel D, Loschmann YN, Schmidt HH, Scholer HR, Cantz T, Heneka MT (2011) Neuroinflammatory and behavioural changes in the Atp7B mutant mouse model of Wilson's disease. J Neurochem 118:105-112. https://doi.org/10.1111/j.1471-4159.2011. 07278.x
Theophilos MB, Cox DW, Mercer JF (1996) The toxic milk mouse is a murine model of Wilson disease. Hum Mol Genet 5:1619-1624

Ullah K, Hashmi MZ, Malik RN (2014) Heavy-metal levels in feathers of cattle egret and their surrounding environment: a case of the Punjab Province, Pakistan. Arch Environ Contam Toxicol 66:139-153. https://doi.org/10.1007/s00244-013-9939-8

Wijnhoven S, Leuven RS, van der Velde G, Jungheim G, Koelemij EI, de Vries FT, Eijsackers HJ, Smits AJ (2007) Heavy-metal concentrations in small mammals from a diffusely polluted floodplain: importance of species- and location-specific characteristics. Arch Environ Contam Toxicol 52:603-613. https://doi.org/10. 1007/s00244-006-0124-1

Xiao K, Kondo Y, Sakuma Y (2004) Sex-specific effects of gonadal steroids on conspecific odor preference in the rat. Horm Behav 46:356-361. https://doi.org/10.1016/j.yhbeh.2004.05.008

Yoshida MC, Masuda R, Sasaki M, Takeichi N, Kobayashi H, Dempo K, Mori M (1987) New mutation causing hereditary hepatitis in the laboratory rat. J Hered 78:361-365

Youngers PL, Banwart SA, Hedin RS (2002) Mine water; hydrology, pollution, remediation. Kluwer Academic Publishers, The Netherlands

Zounkova R, Jalova V, Janisova M, Ocelka T, Jurcikova J, Halirova J, Giesy JP, Hilscherova K (2014) In situ effects of urban river pollution on the mudsnail Potamopyrgus antipodarum as part of an integrated assessment. Aquat Toxicol 150:83-92. https://doi. org/10.1016/j.aquatox.2014.02.021 